\title{
UNIVERSITYOF
}

FORWARD

THINKING

WESTMINSTER用

WestminsterResearch

http://www.westminster.ac.uk/westminsterresearch

\section{A Comparative Cyberconflict Analysis of Digital Activism Across Post-Soviet Countries}

Karatzogianni, A., Miazhevich, G. and Denisova, A.

This is the peer reviewed version of the following article: Karatzogianni, A., Miazhevich, G. and Denisova, A. (2017) A Comparative Cyberconflict Analysis of Digital Activism Across Post-Soviet Countries, Comparative Sociology, 16 (1), pp. 102-126, which has been published in final form at:

https://dx.doi.org/10.1163/15691330-12341415

The WestminsterResearch online digital archive at the University of Westminster aims to make the research output of the University available to a wider audience. Copyright and Moral Rights remain with the authors and/or copyright owners.

Whilst further distribution of specific materials from within this archive is forbidden, you may freely distribute the URL of WestminsterResearch: ((http://westminsterresearch.wmin.ac.uk/).

In case of abuse or copyright appearing without permission e-mail repository@westminster.ac.uk 


\title{
A Comparative Cyberconflict Analysis of Digital Activism Across Post-Soviet Countries
}

\author{
Athina Karatzogianni \\ University of Leicester \\ athina.k@le.ac.uk \\ Galina Miazhevich \\ University of Leicester \\ gm223@leicester.ac.uk
}

Anastasia Denisova

University of Westminster

A.Denisova1@westminster.ac.uk

\begin{abstract}
It is more common for digital activism scholarship to focus on a political event, movement or organization, or the use of Information Communication Technologies (ICTs) in a single country, case study or incident, rather than utilizing a comparative politics and sociology approach across several countries. This article analyses digital activism comparatively in relation to three Post-Soviet regions: Russian/anti-Russian during Crimea and online political deliberation in Belarus, in juxtaposition to Estonia's digital governance approach. We show that in resistant civil societies in Russia, Ukraine and Belarus, cultural forms of digital activism, such as internet memes thrive and produce and reproduce effective forms of political deliberation. In contrast to Estonia which tops the internet freedom table and is innovating in digital governance with the e-residency program, in authoritarian regimes actual massive mobilization and protest is forbidden, or is severely punished with activists imprisoned, persecuted or murdered by the state. This is consistent with use of cultural forms of digital activism in countries where protest is illegal and political deliberation is restricted in government-controlled or oligarchic media. Humorous political commentary might be tolerated online to avoid mobilization and decompress dissent and resistance, yet remaining strictly within censorship and surveillance apparatuses. Our research affirms the potential of internet memes in addressing apolitical crowds, infiltrating casual conversations and providing symbolic manifestation to the burning resistant debates. Yet on the other hand, the virtuality of the protest undermines its consistency and impact on the offline political deliberation. Without knowing each other beyond the social media debates, the participants are unlikely to form robust organisational structures and mobilise for activism offline.
\end{abstract}

\section{Keywords}

comparative digital activism, Russia, Crimea, Belarus, Estonia, internet memes, digital governance, resistance 


\section{Introduction}

Scholarship on issues surrounding digital activism is booming. Over the past twenty years there has been extensive work on surveillance and censorship issues (Morozov 2011; Fuchs et al. 2012; Bauman and Lyon 2013); the impact of ICTs on the ideology, organization, mobilization and structures of new socio-political formations (McCaughey and Ayers 2003; Van de Donk et al. 2004); the role of digital networked everyday media in supporting social movements and protest groups around the globe (Karatzogianni 2006; Dahlberg and Siapera 2007; Castells 2012); and the influence of non-state actors in deliberating in the digital public sphere the ethics and rights in all levels of governance, connecting with important issues such as migration, the environment, the rights of cultural and other minorities (Zuckerman 2013; Karatzogianni et al. 2013; Gerbaudo 2016).

There is, however, limited systematic comparative sociopolitical research in the digital networks and communication domain. In particular, there is little work which not only directly addresses digital activism, cyberconflict, and questions of digital governance and resistance, such as censorship, surveillance and cybersecurity, but also provides comparative perspectives on media industries, political institutions, and socio-cultural processes, across regions, countries, and continents. This article offers a limited glimpse of such an undertaking. It advocates that a comparative cyberconflict approach could offer new insights into the interaction between different types of regimes and the corresponding resistances they confront, intersecting with the political economy of digital everyday networked media and its material influence on the political cultural systems across different geographical regions.

The transnational character of digital media does not forbid a comparative digital activism approach across countries. On the contrary, a broader comparative sociopolitical and cultural approach into the study of digital activism is long overdue. Current efforts by scholars in this area of initiating permanent observatories, in national and regional terms, points still to the relevance of nation states and their influence in policy making and regulation of digital spaces, despite the globalizing nature of the technology. In fact, in the past five years in particular, states and corporations have been competing and blaming each other for conflicts and tensions relating to issues of privacy, cybersecurity, intelligence and data protection of citizens and consumers alike. Civil society actors in turn, often times funded by governments and corporations, find themselves in the position of defending civil and human rights, fighting censorship, surveillance and state prosecution of dissidents, activists, artists, investigative journalists, and whistleblowers, such as Edward Snowden, Chelsea Manning, Julian Assange, Ai Wei Wei, Glenn Greenwald, Laura Poitras, Amy Goodman, and other less prominent individuals, groups and populations, which are striving for liberalization, democratization, transparency, freedom of information, and the protection of digital as human rights. State secrecy privilege, attempted extradition and national legal jurisdictions have often been at the center of these combative exchanges.

This article is co-authored by three scholars researching particular themes and regions using diverse research techniques ranging from semiotics, digital ethnography and indepth interviews. Methodologically, we utilize a two-fold strategy which combines 
cyberconflict analysis with comparative political sociology. In mid-level theory terms, cyberconflict theory (Karatzogianni 2006; 2015) initiates a comparative examination of digital activist networks in Belarus and the Crimea during the Ukraine-Russia conflict in juxtaposition to Estonia. Cyberconflict integrates social movement, digital media network theory in conjunction with international conflict analysis to examine the following elements: a. historical, socio-political, economic and digital environment; $b$. mapping the levels of mobilization in each country and ideological orders of dissent against which socio-political code, within what labor process, with which type of agency and social logic; c. the impact of ICTs on mobilizing structures, framing processes and the political opportunity structure within each country environment $d$. the ethnoreligious and cultural elements produced and reproduced in digital networks; e. the control of information, surveillance, censorship, political discourse dominance, and digital effects on policy.

The second broader theoretical strategy is drawing the cyberconflict frame into dialogue with Rezaev et al. (2015) and their Marxian materialist interpretation. The purpose of this is to compare agency, processes and structures of digital activism in the three countries, following broader lines of inquiry within comparative political sociology research. Going beyond the necessary injection of Marx into internet studies (Fuchs and Dyer-Witheford, 2012 and subsequent contributions of Fuchs in this area), we follow the argumentation by Rezaev et al.: "the materialist interpretation of history does not postulate determinism of the 'economic', but rather asserts that the social relations have their own causal importance structuring the entire human life process" (Rezaev et al. 2015: 460). Furthermore, digital cultural economies (Garnham 1995 [2015]; Matthews 2015) form the material cultural structures within which digital activism thrives and produces and reproduces itself, especially under authoritarian regimes where actual massive mobilization and protest is forbidden, or is severely punished with activists imprisoned, persecuted or murdered by regimes. The digital cultural terrain is therefore, where we turn to next.

\section{Digital Political Culture and Resistance Publics}

Over the last two decades, the development of new technologies and virtual networks has led to the emergence of new types of mediated interaction between individuals. In the Internet-enabled 'participatory culture' (Jenkins 2009), any person with digital access can become a user and producer of media at the same time. Bruns (2007) calls this new practice "produsage", a portmanteau of "production" and "usage" that implies that anyone can post a story, share a story or become a media of his own by sharing personal information and updates online. Participatory culture has transformed the ways people talk and coordinate for civil and political causes, circulate cultural products and interact on a personal and social level (O'Reilly 2005; Szilvasi 2011).

Yet digital space is not inherently democratic: intellectuals often dominate the production of authentic ideas and viewpoints (Scholz 2008; Chomsky 2011). Jenkins (2009), Scholz (2008) and Chomsky (2011) argue that social media and participatory 
culture may equally promote or limit democracy, depending on a variety of factors. The more resourceful actors such as large institutions and corporations possess more influence over the discourse than individual users. Moreover, their own public relations elements have undergone a generation shift in the last decade, rendering them more comfortable in a demassified media environment (Morozov 2013).

Despite these challenges, new digital communication formats, such as self-expression and discussions on social media networks, have become an important tool for political talk and protest mobilizations (Bennett 2003). The online political communicators can use different kinds of framing and styles of language to attract the previously passive and disengaged users (Garrett, 2006). Van Laer (2007: 5) applies the term "political socialization" to describe the online political discussion that users accidentally fall into - it may start as mundane talk in a digital network, transform into a political debate and then result in further political mobilization and action in the offline realm. Social media networks thrive on open communication, and the ability to follow or to broadcast to an array of communities at any given time.

Zuckerman's (2013) theory of "latent capacity” (or the "cute cat theory” of political activism) is valuable for this research: even those users who are normally neither interested nor involved in politics can receive political information and ideas when they browse the newsfeed produced by their network of friends. These politically disengaged users may notice the political memes and other light versions of political information, shared by their contacts. Should an issue arise that appeals to a politically passive person and incites them to raise their voice, he or she is already equipped with the audience of networked "friends" to share the political content with. People may suddenly "use their online presence” (Zuckerman 2013) for political purposes and join the pre-existing dissent communities. Accordingly, as Li (2010) notes, even casual conversations and gossip on social networks play the role of a subtle digital adhesive that assists in building trust among the members of the conversation.

Popular social media networks advance the personalised self-expression online: people tweet or post images and text under their names and pseudonyms; they do not need to belong to a forum, a community or any group to benefit from the visibility and feedback of the others (Estevesand Meikle 2015; Meikle, 2014). The development of digital media has contributed to the increasing power of emotions and storytelling in contemporary dissent practices (Karatzogianni 2012; Papacharissi 2015; Theocharis 2015). Interactive social media amplify the tradition of storytelling and "invite people to feel their own place in current events, developing news stories, and various forms of civic mobilisation” (Papacharissi 2015: 4). Karatzogianni (2012: 245) has suggested that "affective structures mediate between the actual and the digital virtual"; they create a new realm of engagement and of experiencing the protest. Participants of digital mobilisations construct and promote "virtualities" of hope, freedom, aspiration, fear and hatred (Karatzogianni 2012: 53). Social media users can connect, respond and further shape these virtualities and digital narratives: they can supplement their own subjective interpretations and express their endorsement or disagreement with the suggested stories (Papacharissi 2015). 
Clearly, the rise of digital social media has boosted the capacity of individuals to express themselves online and become noticed by the others. Theocharis (2015: 2-3) asserts that what we understand by "political participation" has significantly changed in the era of digital media. Any manifestation of one's political views, persuasion of others and politicized artistic contributions to the digital sphere (memes, tweets, jokes and other casual conduits of communication) can qualify as the practices of political participation. The act of "mobilization", therefore, can be defined as the deliberate activation of social networks to diffuse political information and influence the opinions of others (Theocharis, 2015: 5); it does not call for offline action of establishment of organizations or structures. Networked political participation constitutes the alternative logic of political engagement; when online, individualistic motives and modes of expression prevail over collective ones.

Instead of brokering differences between formal groups and organizations, negotiating collective identity frames, individuals now co-operate and share personalized frames and expressions of individual ideas, opinions and creativity (Bennett and Segerberg 2012). The Internet provides numerous platforms and networked communities that facilitate the rapid articulation of political views and beliefs to individuals and groups. Bennett and Segerberg (2012) note the change of discourse in political discussions and mobilizations. They use the open Occupy mobilization as an example of a shift of narrative, where the conventional "who we are" discourse of classic political communities was replaced by personalized frames. However, in order for these frames to acquire attention amid the multitude of other individual frames, collective processes are required. Bennett and Segerberg (2012) offer the idea of “connective action” as the contemporary substitute for collective action in protest mobilization. By connective action, they refer to political mobilizations that do not require established leaders and organizations, but aggregation of users who self-organize via digital platforms. However, they note that in most current mobilizations, both types of action are present in hybrid ways.

From a different perspective, social media users not only emotionally engage with the political discourse, but often deliberately utilize social networks to change the public opinion or popular ideas. They seek to fill the gap left by the mainstream media and disrupt the hegemonic ideology, provide alternative perspective and articulate nonconventional issues (Lievrouw 2011; Lasn 1999). Four main characteristics define alternative media: "the use of medium as content, the rejection of ideology, the merging of politics and art, and appreciation of the ability of digital information to directly make things happen” (Braman 2002, cited in Lievrouw 2011: 17). Following Lievrouw (2011) and Atton (2004), we view artful political communication as alternative activist media; their accounts serve as participatory, non-commercial liberating channels and practices that unite political content, social responsibility and artful expression. Atton calls these alternative new media "actions in their own right", rather than a platform for broadcasting about "real” actions (Atton 2004: 5; see also Raley 2009: 5-6).

In the last decade, politically active users in different countries have exploited the Internet memes for deliberation (Li 2010; Pearce 2014; Bennett and Segerberg 2012). 
Internet memes are the viral units of digital communication that flourish on user adjustment and replication (see Knobel and Lankshear 2007; Shifman 2013). Media and communication scholars assessed memes as the folklore and casual language of the digital crowds (Milner 2013; Esteves and Meikle 2015), aesthetic artifacts of electronic communication (Goriunova 2013) and strategic discursive weapons of political activists (Metahaven 2013; Li, 2010), among others. According to the latest group of thinkers, politically active citizens exploit memes as the "mindbombs", or symbolic texts with condensed ideas and ample connotations, that help to attract attention to the political issues, suggest alternative interpretations to the news and encourage debates among users (see Shifman 2013; Zuckerman 2013). These metaphoric codes have proved to be an effective way to escape government surveillance, yet still inform other users of alternative viewpoints and spread a more critical perspective. In the following section, we examine the use of internet memes, imagery and humor in Russian/Ukraine digital activism over Crimea and also Belarus to provide empirical evidence and engage in a comparative analysis between these and the digital environment in Estonia, which is chosen here to illustrate the importance of regime type in explaining how activism occurs in digital political culture.

\section{Crimea and Belarus: The intersection of historical, political and digital conflicts}

\section{Crimea}

The Russian media environment of the 2010s has become a turbulent space for the deliberation of alternative political discourses. The government has been promoting its agenda through a variety of national broadcasting, radio, press and Internet outlets; the level of indoctrination significantly increased by the mid-2010s (Kachkaeva 2015). By this time, the state had successfully shut down or curbed the influence of leading independent media that used to hold the elites to account. Liberal publics have largely relocated to social networks and various Internet media as the nonconventional sources of information, opinion and political ideas (Yuhas 2014). Due to the lack of established independent media, many resistant Russian citizens have exploited social networks to criticise the Kremlin. Resistant microbloggers have actively employed satirical means of expression, such as ironic tweets, parody and Internet memes (Bugorkova 2015).

Internet memes are viral texts that proliferate on mutation and replication. They often contain a humorous ambiguous joke that calls for the user's awareness of the broader context for interpretation (Knobel and Lankshear 2007; Shifman 2013; Meikle 2014). Russian social media users utilised memes to suggest non-hegemonic ideas around the inner motives of the Russian elites, to oppose the misrepresentation of facts by hegemonic media and absence of opportunities for dissent (Bugorkova 2015; Yuhas 2014). The proliferation of these viral digital artefacts prompted us to examine Internet memes as innovative practices of political activism and communication of the state supporters and resistant publics in Russia. The Crisis started in February 2014, when Russia intervened in the domestic conflict in Ukraine and facilitated the independence referendum in the Ukrainian peninsula of Crimea, known for its Russian-speaking majority. Russia incorporated the peninsula into its territory in March 2014, prompting 
harsh international criticism and domestic debates in Russia over the legitimacy of this move. During the Crimean episode, social media users were actively discussing the legitimacy of Kremlin's actions, commented on the instances of state propaganda and encouraged criticism of the elites.

Since 2011, Internet memes have gained a reputation as the in-jokes of digitally savvy users: the main opposition politician Alexey Navalny has been constantly using memes in his Twitter, blog and standalone website (Bugorkova, 2015; Rothrock, 2014). Many meme sharers from our sample agreed that this was a smart rhetorical strategy: independent liberal users enjoyed memes as the celebration of informal Internet communication. From this perspective, the exploitation of memes by liberal users enhanced the role of memes as discursive weapons and 'mindbombs'. In the Russian political environment, interviewees suggested, satire and memes can be meaningful and precious in offering "a specific lens that can often convey the essence of a political event much sharper than ten highly intellectual newspaper columns” (A. Kovalev, personal communication, 15 June 2014). In political discussion on Russian Twitter, dissent users employed memes as symbolic manifestations of protest discourse that operated the language of the Internet crowds and appealed to other dwellers of digital networks.

\section{(Insert IMAGE1Crimea)}

Curiously, during the 2011-12 anti-government protests in Russia, many memes from the Facebook resistant groups, transferred to the offline posters of the activists in Moscow and St Petersburg. This example shows that, when the public gatherings were allowed, the activists were inclined to connect the virtual space with offline mobilization. However, once the harsh fines and possibility of a prison sentence were enforced in Russian against any political protest exceeding six people (Malgin 2014), the offline protest public ceased attending rallies. Accordingly, the memes stopped appearing in the protest demonstration. Nonetheless, memes still sometimes appear in the offline realm in anti-corruption cases. Politicians and their communication professionals utilize the language and visual format of memes to address their potential electorate. Alexey Navalny, who has been promoting the exploitation of memes in his blogging and microblogging, still employs memes for his political campaigning, including posters and leaflets (Navalny 2016). His efforts are for the moment among the very few examples of the memes' fluidity between the electronic and material spaces.

Memes are not limited to the liberal and resistant users. Interviewees pointed out that familiarity with the logic and formats of communication in social networks may signify tendency towards independent thinking yet does not serve as an objective steady identifier of dissent users, (@KermlinRussia 10 July 2014; @Fake_MIDRF 9 September 2014). Furthermore, the pro-government public also employs digital networks; half of the country is registered on and frequently logs in to social media (45\% of Russians and 53\% of Muscovites (Volkov and Goncharov 2014)). However, these users are more likely to spend their time on major domestic networks, such as Odnoklassniki and VKontakte, which are mostly in Russian and unite people of various 
ages and backgrounds, with a significant number of middle-aged and senior users (Volkov and Goncharov 2014). Facebook, Twitter and Instagram are considered trendier among the citizens of large cities with the ability to post in English and share links in different languages. Liberal meme makers from our sample (see, for instance, @KermlinRussia 10 July 2014) complained that the majority of the country's population is online yet prefers other realms than those with progressive views. From this perspective, communication in social networks and digital literacy are not reserved to the liberal users. Pro-government users also share memes and post them to various networks, from Odnoklassniki to Twitter. Therefore, there is not enough evidence to claim that meme literacy is the identifier of the politically active and digitally savvy user. Instead, memes are the casual format of expression, contemporary lingua franca of the Internet crowds, which people with various political standpoints can exploit to their liking.

\section{[Insert IMAGE2Crimea]}

Yet liberal meme makers pointed to a specific feature of memes that helps to employ them in liberal communication and building trust among disperse critical users. One of the popular liberal media Lenta.ru largely exploited Internet memes in their Twitter channel in 2011-2012. This style of communication enabled journalists to oppose the verbose formal narrative of traditional media and promote more personal relationship with their social media followers. Through jokey tweets and memes, this popular liberal news website appeared as a "warm" media that consisted of people with emotions, sympathies and opinions, rather than a distant, cold information outlet (Belkin 26 June 2014). This finding suggests that dissent users may attribute more value to communication via memes than pro-government crowds. For the resistant social media users, networking platforms and memes are among the few remaining conduits of free expression and deliberation of ideas, which makes every element of them more precious.

Overall, the analysis of the Crimean memes and interviews with the prominent Russian resistant meme sharers has demonstrated that the role of memes as discursive weapons is constantly evolving. The challenges of the authoritarian environment placed increasing pressure both on traditional and new media. Nonetheless, they encourage the liberal accounts to sustain alternative discourse by all available means. Social network spaces are becoming the ultimate sources of uninhibited data and commentary. Although many liberal users perceive memes as pleasurable additions to the meaningful textual discourse, they nonetheless affirm their potential in addressing apolitical crowds, infiltrating casual conversations and providing symbolic manifestation to the burning resistant debates. On the one hand, it suggests studying their online personas as independent actors of communication. Yet on the other hand, the virtuality of the protest undermines its consistency and impact on the offline political deliberation. Without knowing each other beyond the social media debates, the participants are unlikely to form robust organisational structures and mobilise for activism offline.

\section{Belarus}


Belarus became an independent country after the fall of the USSR in 1990. Formerly a western periphery of the Russian Imperial State and then the Soviet Union, Belarus is now a buffer zone between the EU and Russia. It is an authoritarian state governed by President A. Lukashenko since 1994 (Rice-Oxley 2014). Belarus remains closely ideologically linked to its Soviet past and is frequently referred to as the "last Soviet republic" (Parker 2007). Belarus has two official languages - Russian and Belarusian. Majority of the population (72\% of the 9.7 million people in Belarus) uses Russian language (Population Census 2009).

In common with other former Soviet Union republics, state control over traditional media and media self-censorship is pervasive in Belarus (Rice-Oxley 2014). The establishment tends to use strict libel legislation and unrelated laws (e.g. on hooliganism) frequently to maintain a "tight rein on information" (Aliaksandrau 2013). Freedom House ranks Belarus as 193rd out 196 countries, having a "not free status" as it lacks freedom of speech and press. Additionally to control over traditional media there are restrictions on what online content can be accessed (Freedom House, 2013).

A particular path of new media development and lack of theorisation of new media potential for digital activism in Belarus makes this inquiry particularly timely. The Belarus media landscape - previously dominated by relatively low Internet penetration and high cost of Internet usage - is changing rapidly, as the Internet becomes more accessible and affordable (especially) via mobile devices. The speed of internet take up places Belarus in one of the top 20 countries in the world; broadband use has increased from 10\% in 2010 to almost 70\% in 2012 (Aliaksandrau 2013). In 2012, approximately half of the population of Belarus used the internet (47\%) and mobile phone webconnectivity is on the rise. $24 \%$ of Belarus's urban population accesses the Internet via a mobile phone or smartphone. The 3G standard is becoming more affordable (Pet'ko, 2013), as the mobile internet providers compete for a market share. The Internet users are predominantly young (30\% of the online audience are between 15 and 24) and welleducated-nearly 40\% have higher degree (Aliaksandrau 2013). The most popular social platform is Russian-language VKontakte followed by Odnoklassniki.

While cyber-optimists perceive online platforms as (almost) the only available public space to exercise local governance in emerging democracies, there are various obstacles counteracting the process of democratization in Belarus. As the case of post-Soviet Belarus demonstrates, new media ecologies play out differently in such a socio-political environment. Despite several successful online public initiatives to date, such as a protest after the unfair use of force by traffic police as discussed by Lobodenko and Kozlik (2008), the new media interventions remain mostly sporadic one-off localised initiatives.

This can be explained by a number of factors nested in the post-Soviet communication ecologies. In order to clarify this, one needs to look into a so-called "virtual democracies" phenomenon (Wilson 1995) or a lack of well-established and functioning vertical structure of credible institutions in the post-Soviet region. As a result an 
essentially horizontal communication network galvanized by the rise of the Internet frequently stays at the level of predominantly online (rather than offline) civic initiatives. The fall of the communism and irregular transition to a new ideological system resulted in misunderstanding of the notion of democracy, its principles and values. For instance, Semetko and Krasnoboka (2003: 79) state that "while democratic principles, norms and procedures may be admired, the political party, a primary institutional feature of established democracies, is not". Belarusians "mostly trust public organizations supported by the state [] believe that civil society is controlled by the former [and] do not see civil society as an intermediary between them and the state" (Brel 2015). The weak civic society translate into passivity and a narrow set of issues of public concern (Artsiomenka 2015).

The weak civil society manifests online as a pronounced self-censorship, fear and mistrust (Herasimenka 2016). Fossato et al. (2008) states that the individuals often are contacted by Russian state officials and pressured to conform to "rules". In the case of Belarus -a relatively small country-the self-censorship stems from the fact that "anonymity" of online activists can be even easily uncovered and their identity/location is traced. This is an opinion disclosed to us in a confidential interview by one of the prominent Belarusian independent political analysts in 2011. It exerts a pronounced impact on online civic engagement among Belarusian digital activists based in the country. On the whole, the patterns of Internet usage mimic the importance of informal offline networks. Online users and groups tend to seek advice via established informal networks and to engage in discussions within confined online circles (Fossato et al. 2008).

A related dilemma to the democratising potential of the Internet is its regulation. Similarly to other post-Soviet states, Belarus adopted stringent legislation preserving centralised access and expanding the surveillance powers. The SORM ICT monitoring system used in Russia is also employed in Belarus (Freedom House Report 2013: 8). Together with to the first generation of control mechanisms (e.g. surveillance of internet cafes and filtering), the state uses the second generation of control - a legal and normative environment to block access to information or (Deibert and Rohozinski 2010). In fact a 2010 regulation presupposed a "compulsory registration of all websites and the collection of personal data in Belarus" (EDRI-gram 2010). The "active surveillance and data mining" (Deibert and Rohozinski 2010: 27) is combined with the state-sponsored dissemination of propaganda, misinformation and kompromat (compromising material) online. These features comprise a more sophisticated thirdgeneration control mechanisms.

Operating in parallel to these measures, there are some other more "subversive" tactics involving promotion of stability and affordable entertainment, such as access to the latest films online. In addition to the infotainment tactic (Miazhevich 2015), cyberspace can be used for managing dissent. By monitoring online space for a public dissent, the establishment ensures early control over key dissenters/issues and encourage "slacktivism", a feel-good online activism that has zero political or social impact (Morozov 2011). 
Nevertheless, subversive tactics online can be employed by various actors. Similar to the Crimean incident, also in Belarus, Internet memes have become one of the wider spread non-hegemonic tactics due to the ease and relative safety of their production and dissemination. The circulation of these online grassroots satirical images explicates the difficulties involved in controlling information flows online. This is partially due to the impossibility of exerting control over "multiple" readings of the satirical messages. Three examples below contextualize challenges to authoritarian governments seeking to maintain control over media output and reception.

\section{[Insert IMAGE3Belarus]}

This first photo is the altered image of the band Rammstein from Kerrang magazine. This version has the blogger Lipkovich, who published the item in question, on the far right with a black censure tape across his eyes. On the far left of the photo we can see a superimposed images of the head of the Union of Writers, M. Charhinets. Access to the blog was temporarily blocked and he faced criminal charges for desecrating a flag, which were later dropped. One of the motives behind the prank stemmed from the fact that Charhinets, as the head of Public Morality Council, considered banning Rammstein's performance in Minsk (Khvoin 2012).

\section{[Insert IMAGE4Belarus]}

This photo has three layers of satirical meaning to it. The first one refers to these three militia men (policemen) who were photographed chasing after a car in the capital of Belarus, Minsk. This caption was used in a number of satirical images. Here they are superimposed on a previously circulated image - a special unit chasing presumably an oppositional protestors after 2010 presidential elections (http://kaputmaher.livejournal.com/78922.html). However, the text refers to an economic crisis in Belarus, which happened afterwards. It was marked by shortages of foreign currency and some of the food supplies (e.g. buckwheat). So the dialogue underneath is the following: An old lady coming out of the foreign exchange office: “My sons, do you have any foreign currency?” They reply to her: "No, mother, we are in a rush to get some buckwheat".

\section{[Insert IMAGE5Belarus]}

This is one of the most recent examples of online satire: a reaction to a ban of western produce in Russia. Belarus became a grey importer of the banned products such as French cheese, Norwegian salmon, Polish apples, etc. presenting them as "produced in Belarus". Thus, these grassroots satirical images explicate the subversive potential on online satire in a constrained post-Soviet mediascape.

\section{The comparison to Estonia}


So far, we have examined online satire and memes, demonstrating their strengths in providing a flexible and accessible way to challenge regimes and counter-hegemonic discourses on the one hand and their limitations in impacting the organization and mobilization of protest in authoritarian regimes on the other. Estonia is juxtaposed here as a post-Soviet state which differs significantly from the two regions explored, due to the stark different approach to digital governance, which in turn is influenced by the historical and political material processes within which it is produced.

Estonia represents a fascinating control case because of its rather different post-Soviet trajectory. Undertaking a much more radical shift in its conceptualization of the role of media and communications, it abandoned a public service ethos in favour of rapid market liberalization. Thereafter, censorship in Estonia and indeed across all the Baltic states was largely self-regulation. Some have argued that, within a relatively immature civic and media culture, Estonia has developed a unique form of 'reversed' censorship in which we not only see a very liberal media, but also a deliberate media effort to limit the any suggestion that there might be limits placed on the new-found freedom of expression. This ideology of a free expression is in part an expression of the power of the media that have been hostile to external criticism (Lauk and Jufereva, 2010). One might also add that historians suspect that Sovietization during the Cold War was not as deep in Estonia as that witnessed in places like Belarus and the Ukraine (Kreegipuu and Lauk, 2010).

Accordingly, the 2016 map of internet freedom by Feedom House, saw Estonia ranking the highest in terms of internet freedom (Transitions Online 15 November 2016). This is despite what is now a famous cyberconflict incident occurring in 2007, when ethnic Russians brought the internet down for a month in protest of a war statue memorial removal from the center of Tallinn and the reaction of the Estonian government asking NATO to evoke article 5 against Russia (see Karatzogianni, 2009. In the same report, Belarus, Kyrgyzstan, and Russia remained "not free", as "increased access to user data and closer surveillance by authorities, as well as increased persecution of social media users were registered in all three countries, while Russia also saw an increase in physical violence against social media users”.

The Freedom House report (Freedom on the Net 2016: Estonia) refers to Estonia as "a model for free and open internet access as a development engine for society". It refers to the country's Digital Agenda 2020, which outlines

How both technological and organizational conditions will be developed to ensure that people will always know and be able to decide when, by whom, and for what purpose their personal data is being used in the public sector. The same agenda also launched an "e-residency" program to offer its secure and convenient online services to the citizens of other countries. Services include digital authentication, digital signatures, encrypted transmission of documents 
and other electronic communications, and access to all Estonian public and private sector online services.

The stark contrast of the Crimea and Belarusian digital activism to Estonia lies in the fact that the Estonian government is riding the wave of demands for digital rights, and transparency as they have become the country's public, social and digital policy agenda. Nevertheless, Lorraine Weekes (2016) explains in her ethnographic study of digital governance in Estonia that the government embraces the neoliberal agenda of platformizing citizenship full stock and barrel by utilizing corporate rhetorical devices as well as cutting edge technological tools (i.e. blockchain-related innovations):

Even as e-Residency's main selling point is that the individualizing digitalidentification service it offers is provided by a state, i.e. that people anywhere in the world can be bureaucratically mediated by the government of Estonia in a manner that has historically been available only to citizens and residents, the e-resident "subject position" that emerges in the elite discourses surrounding e-Residency and the day-to-day work of the team is that of a consumer or user. In other words, the political dimensions of the state-citizen relationship are obscured or erased by the techno-legal infrastructure of e-Residency.

\section{Conclusion}

Our analysis has revealed several issues regarding digital activism in the Post-Soviet sphere by showcasing two examples within authoritarian regime structures and briefly juxtaposing this to a country, which has embraced digital democracy, transparent electronic governance and freedom of information to the full. The structural conditions, the materiality of government, digital, socio-economic and political infrastructures exert significant influence, not only on the level of internet freedom, but also directly define the type of digital activism occurring under diverse regimes.

Further, social media networks are not the causes of digital activism, they are expressive enablers for political participation and deliberation as in our case here. They may well accelerate mobilization, as they did during the "Arab Spring”. Nevertheless, with neoliberal structural adjustment programs creating inequalities, food crises, youth unemployment and precarity, corruption and deep cleavages acting as the material conditions defining the social and political relations and resistances produced in that period (Karatzogianni, 2015). They resulted in regime change, but not in a social revolution. In other cases, social media participation may act as substitute for actual mobilization depending on the regime type (for instance see research on Chinese dissidents. ibid.).

Significantly, the geopolitical and International Relations context is crucial, and in the post-Soviet case here, it is also influenced by the legacy of Cold War rhetoric. For instance, the DCLeaks of the summer 2016 revealed that Soros through his Open 
Society Foundation funded research on how the Crimea crisis was perceived in the media of various countries, which accompanied revelations about Soros also funding the Black Lives Matter movement, and subsequent allegations that he similarly funded the Anti-Trump protests after the American election result in November 2016. The DNC Leaks which are attributed by the Obama Administration to the Russian state is another example of the high importance of ICTs in current geopolitics.

In that broader context, digital activism has become a fabric of everyday political life with diverse types, levels and ideological orders of dissent. Whether online dissent will result in offline mobilization is not a question of technology only, but of digital governance embedded in offline structural material conditions (i.e. the military, policing, surveillance and security infrastructure). The digital environment is controlled by tech corporations and nation states which strive to embody and barricade digital space for profit in the former case and national security in the latter. The role of the state and capital, in backing non-profit platforms as providers of public service, making up what the state cannot provide and corporations can redeem as social responsibility tokens, is a red herring concealing the dismantling of local work forces into transnational online labour markets, which are unregulated in terms of liability, taxation, insurance and social protection. In this sense, digital activism in all its variations is a symptom of citizens demanding rights and social justice in societies dissenting against transnational capital and the neoliberal order, the local, regional and national elites serving this order.

In the cases we examined comparatively here, the softer humorous internet memes and political commentary are tolerated as decompressors by authoritarian regimes, because they act as welcome alternatives to protest mobilizations which have real potential for regime change. And yet, by offering an outlet for political deliberation and dissent, these cultural forms of digital activism, materialize resistance bring the revolutionary virtual closer to its capacity to affect sociopolitical change.

\section{Bibliography}

Aliaksandrau, A. 2013. "Belarus: Pulling the Plug”. Index on censorship. Available at: https://www.indexoncensorship.org/wpcontent/uploads/2013/01/IDX_Belarus_ENG_WebRes.pdf

Artsiomenka A. 2015. “(De)-consolidation of Civil Society in Belarus: Decreased Potential for Solidarity Action, De-politicisation, Disagreement about values”. Civil Society in Belarus 2000-2015 Collection of Texts. Warsaw: East European Democratic Centre. Available at: https://issuu.com/eedc_warsaw/docs/final_civil_society_in_belarus_inte_5d21802f64 $\underline{0249}$

Atton, C. 2004. An Alternative Internet. Edinburgh: Edinburgh University Press. 
Bauman, S. and Lyon, D. 2013. Liquid Surveillance: A Conversation, Cambridge: Polity.

Belkin, I. 24 June 2014. Interview with Anastasia Denisova, Moscow.

Bennett, W. L. 2003. New Media Power: The Internet and Global Activism in Contesting Media Power edited by J. Couldry and N. Curran. Lanham: Rowman and Littlefield.

Bennett, W.L. and Segerberg, A. 2012. “The Logic of Connective Action”. Information, Communication \& Society, 15:739-768.

Brel Y. 2015. "Re-envisioning Civil Society in the Republic of Belarus”. MA Dissertation. University of Delaware, School of Public Policy and Administration. Available at: http://udspace.udel.edu/handle/19716/17238

Bruns, A. 2007. "Produsage: Towards a Broader Framework for User-Led Content Creation”. Creativity and Cognition: Proceedinds of the 6th ACM SIGCHI conference on Creativity \& Cognition. ACM, Washington, DC.

Bugorkova, O. 2015. "Ukraine Conflict: Inside Russia's 'Kremlin troll army', $B B C$ Monitoring, 19 March 2015. Available at: http://www.bbc.co.uk/news/world-europe$\underline{31962644 .}$

Chomsky, N. 2011. "Responsibility and Integrity: The Dilemmas We Face”. Presented at the lecture for Social Responsibility of the Artist. Utrecht University, Utrecht, March 15.

Castells, M. 2012. Networks of Outrage and Hope: Social Movements in The Internet Age, Cambridge: Polity.

Dahlberg, L. and Siapera, E. 2007 eds. Radical Democracy and the Internet, Basingstoke: Palgrave Macmillan.

Deibert R. and Rohozinski R. 2010. "Control and Subversion in Russian Cyberspace”. Access Controlled: The Shaping of Power, Rights and Rule in Cyberspace. Available at: http://www.access-controlled.net/wp-content/PDFs/chapter-2.pdf

Dion, D. 1998. "Evidence and Inference in the Comparative Case Study”. Comparative Politics, 30:127-146.

Esteves, V. and Meikle, G. 2015. "Look @ this fukken doge": Internet Memes and Remix Cultures" in The Routledge Companion to Alternative and Community Media. New York: Routledge, 561-70.

EDRI-gram. 10 May 2010. “New Belarus Internet Regulations Require Compulsory Web Registration. Digital Civil Rights in Europe. Available at: http://www.edri.org/edrigram/number8.10/censorship-belarus-registration-websites

@Fake_MIDRF. 9 September 2014. Email Interview with Anastasia Denisova. 
Fossato, F. and Lloyd, J. with Verkhovsky, A. 2008. The Web That Failed: How Opposition Politics and Independent Initiatives are Failing on the Internet in Russia. Oxford: Reuters Institute for the Study of Journalism.

Freedom House. 2013. Freedom on the Net 2013: A Global Assessment of Internet and Digital Media. Available at: http://freedomhouse.org/sites/default/files/resources/FOTN\%202013_Full\%20Report _0.pdf

Freedom House. 2016. Freedom on the Net 2016: Estonia. Available at: https://freedomhouse.org/report/freedom-net/2016/estonia

Fuchs, C., Boersma, K. Albrechtslund, A. and Sandoval, M. 2012. Internet and Surveillance: The Challenges of Web 2.0 and Social Media, London and New York: Routledge.

Fuchs, C. and Dyer-Witheford, N. 2012. “Karl Marx @ Internet Studies”, New Media and Society, 15:782-796.

Garrett, R. K. 2006. "Protest in an Information Society. A Review of Literature on Social Movements and new ICTs". Information, Communication \& Society 9:202-224.

Garnham, N. 2015 [1995] "Économie Politique et Cultural Studies: Réconciliation ou Divorce ?”, traduction de Céline Morin, Réseaux 192:45-65.

George, A. L., \& Bennett, A. (2005). Case studies and theory development in the social sciences. Cambridge, MA: MIT Press.

Gerbaudo, P. 2016. 'Constructing Public Space| Rousing the Facebook Crowd: Digital Enthusiasm and Emotional Contagion in the 2011 Protests in Egypt and Spain', International Journal of Communication, 10:254-273.

Goriunova, O. 2013. "The Force of Digital Aesthetics: On Memes, Hacking, and Individuation”. Zeitschrift fur Medienwissenschaft, 8. Draft in English available at: https://www.academia.edu/3065938/The_force_of_digital_aesthetics_on_memes_hac king_and_individuation

Goscilo, H. ed. 2012. Putin as Celebrity and Cultural Icon (Vol. 80). London and New York: Routledge.

Herasimenka A. 2016. "Belarus. Two Hidden Mechanisms of Media Censorship”. Available at: http://www.neweasterneurope.eu/articles-and-commentary/1997belarus-the-two-hidden-mechanisms-of-media-censorship

Ioffe, J. 3 January 2011. "Meet the Persident”. Foreign Policy. Available at: http://foreignpolicy.com/2011/01/03/meet-the-persident

Jenkins, H. 2009. Confronting The Challenges of Participatory Culture for the 21st century. Cambridge, Massachusetts: MIT Press. 
Kachkaeva, A. 11 February 2015. "Voina iz okopov peremestilas na divany”: Anna Kachkaeva o novoy rossiyskoy propagande, Interview by Anna Stroganova, RFI. Available at: http://ru.rfi.fr/rossiya/20150204-anna-kachkaeva/

Karatzogianni, A. 2015. Firebrand Waves of Digital Activism 1994-2014, Basingstoke: Palgrave Macmillan.

Karatzogianni, A. 2010. 'Blame it on the Russians: Tracking the Portrayal of Russians During Cyber Conflict Incidents', Digital Icons: Studies in Russian, Eurasian and Central European New Media, 4:127-150. Online available at: http://www.digitalicons.org/issue04/athina-karatzogianni/

Karatzogianni, A. 2006. The Politics of Cyberconflict, London: Routldge.

Karatzogianni, A. 2012. "Epilogue: The Politics of the Affective Digital. In Karatzogianni, A. \& Kuntsman, A. (eds.) Digital Cultures and the Politics of Emotion: Feelings, Affect and Technological Change. Palgrave Macmillan, 245-249.

Karatzogianni, A., Morgunova, O., Kambouri, N., Lafazani, O., Trimikliniotis, N., Ioannou, G. and Nguyen, D. 2013. "Transnational Digital Networks, Migration and Gender: Intercultural Conflict and Dialogue”. Online MIG@NET.EU Portal: http://www.mignetproject.eu/?cat=10

Kelly. J., Barash, V., Alexanyan, K., Etling, B., Faris, R., Gasser, U. \& Palfrey, J.G. 2012. Mapping Russian Twitter. Berkman Center Research Publication.

Kiriya, I. 2012. "Piracy Cultures| The Culture of Subversion and Russian Media Landscape”. International Journal Of Communication, 6:446-466. Available at: http://ijoc.org/index.php/ijoc/article/view/1196/713

Knobel, M. \& Lankshear. C. 2007. “Online Memes, Affinities and Cultural Production’ in A New Literacies Sampler. New York: Peter Lang, 199-227.

Kreegipuu, Tiiu and Lauk, E. 2010. "Was It All Pure Propaganda? Journalistic Practices Of 'Silent Resistance' In Soviet Estonian Journalism”, Acta Historica Tallinnensia, 15:167-190.

Kovalev, A. 15 June 2014. Email Interview with Anastasia Denisova.

Kremlin. 17 April 2014 Pryamaya Liniya s Vladimirom Putinym, Complete Transcript. Available at: http://www.kremlin.ru/events/president/news/20796

@KermlinRussia. 10 July 2014. Interview with Anastasia Denisova, Moscow.

Kuzio, T. 2015. “Competing Nationalisms, Euromaidan, and the Russian $\square$ Ukrainian Conflict”. Studies in Ethnicity and Nationalism, 15:157-169.

Khvoin, V. 2012. "The Mad Tea Partier of Minsk. TOL. Available at: http://www.tol.org/client/article/23115-the-mad-tea-partier-of-minsk.html 
Laruelle, M. 2014. “The 'Russian Idea' on the Small Screen: Staging National Identity on Russia's TV. Demokratizatsiya. The Journal of Post-Soviet Democratization, 22: 313-333.

Lasn, K. 1999. Culture Jam. New York: Quill.

Lauk, Epp, and Maria Jufereva (2010) Reversed censorship’? Assessing media selfregulation in the Baltic countries, Mediální studia 1:31-46.

Li, S. 2010. "The Online Public Space and Popular Ethos in China. Media, Culture \& Society, 32:63-83.

Lievrouw, L. A. 2011. Alternative and Activist New Media. Cambridge: Polity.

Lijphart, Arend. 1971. "Comparative politics and the comparative method". American political science review, 65:682-693.

Lobodenko, G. and Kozlik, I. 14 March 2008. Za razbitye mashiny iz 'zhivogo shchita' pod Minskom zaplatit GAI? Komsomolskaya Pravda. Available at: http://www.kp.ru/daily/24063/305095/

Mahoney, J. 2007. "Qualitative methodology and comparative politics." Comparative Political Studies, 40:122-144.

Matthews, J. T. 2015. "Passé, présent et potentiel des plateformes collaboratives. Réflexions sur la production culturelle et les dispositifs d'intermédiation numérique”, Les Enjeux de l'Information et de la Communication, 16:57-71.

McCaughey, M. and Ayers, M. 2003. Cyberactivism: Online Activism in Theory and Practice, New York and London: Routledge.

Meikle, G. 2014. "Social Media, Visibility, and Activism: The Kony 2012 Campaign”in DIY Citizenship: Critical Making and Social Media edited by M. Ratto, and M. Boler, Cambridge: MIT Press.

Metahaven. 2013. “Can Jokes Bring Down Governments?” in Memes, Design, Politics. Moscow: Strelka Press.

Milner, R. M. 2013. "Media Lingua Franca: Fixity, Novelty, and Vernacular Creativity in Internet Memes”. Selected Papers of Internet Research, 3.

Miazhevich G. 2015. "Sites of Subversion: Online Political Satire in two post-Soviet states”, Media, Culture and Society, 37:422-439.

Morozov, E. 2011. The Net Delusion: How not to Liberate the World. London: Allen Lane.

Morozov, E. 2013. "The Meme Hustler", The Baffler, 22. Available at: http://www.thebaffler.com/salvos/the-meme-hustler 
Navalny.com. 23 September 2016. Iz zhizni sumerechnykh reptiliy i nochnykh gadov, 23 September. Available at: https://navalny.com/p/5070/\#cut

O’Reilly, T. 2005. What Is Web 2.0: Design Patterns and Business Models for the Next Generation of Software. Available at: http://oreilly.com/web2/archive/what-is-web20.html

Papacharissi, Z. 2015. Affective Publics: Sentiment, Technology, and Politics. Oxford University Press.

Parker, S. 2007. The Last Soviet Republic: Alexander Lukashenko's Belarus. Bloomington, IN: Trafford Publishing.

Pearce, K. 2014. "Two Can Play at That Game: Social Media Opportunities in Azerbaijan for Government and Opposition. Demokratizatsiya, 22(1), 39.

Pet'ko, P. 2013. Podesheveet li mobilnyi internet v Belarusi? Delo.by. Available at: http://delo.by/markets/ shownews/podesheveet-li-3g-internet-v-belarusi

Population Census, 2009. http://www.belstat.gov.by/en/perepis-naseleniya/perepisnaseleniya-2009-goda/

Raley, R. 2009. Tactical Media. Vol. 28. Minneapolis, MN: University of Minnesota Press.

Rees, E.A. 2004. Introduction: Leader Cults, Varieties and Preconditions in The Leader Cult in Communist Dictatorships, edited by Apor, B., Behrends, J. C., Jones, C. \& Rees, E. A. Basingstoke: Palgrave Macmillian, 1-26.

Rezaev, A, Zhikharevich, D., and Lisitsyn, P. 2015. “The Marxist Materialist Interpretation of History and Comparative Sociology”, Comparative Sociology 14:452477.

Rice-Oxley M. 9 June 2014. "Belarus: 20 Years Under Dictatorship and a Revolution Behind the Rest of Europe". The Guardian. Available at: https://www.theguardian.com/world/2014/jun/09/-sp-belarus-remains-revolutionbehind

Roberts, H., \& Etling, B. 8 December 2011. “Coordinated DDoS Attack During Russian Duma Elections”. The Harvard Law Internet and Democracy Blog, 8.

Rothrock, K. 1 March 2014. “The Russians Have Weaponized Photoshop”, Global Voices. Available at: http://globalvoicesonline.org/2014/03/01/the-russians-haveweaponized-photoshop/ 
Ryzhkov, V. 9 April 2015. "Kremlin Doesn't Have Monopoly on Patriotism, The Moscow Times. Available at: http://www.themoscowtimes.com/opinion/article/kremlin-doesnt-have-monopoly-onpatriotism/518902.html

Semetko, H.A and Krasnoboka, N. 2003. "The Political Role of the Internet in Societies in Transition: Russia and Ukraine compared”. Party Politics, 9:77-104.

Scholz, T. 2008. "Market Ideology and the Myths of Web 2.0.” First Monday, 13 (3). Available at: http://journals.uic.edu/fm/article/view/2138/1945

Shifman, L. 2013. "Memes in a Digital World: Reconciling with a Conceptual Troublemaker". Journal of Computer $\square$ Mediated Communication, 18:362-377.

Skocpol, T., \& Somers, M. 1980. "The Uses of Comparative History in Macrosocial Inquiry”. Comparative Studies in Society and History, 22 (1), 174-197.

Theocharis, Y. 2015. “The Conceptualization of Digitally Networked Participation”. Social Media+ Society, 1(2).

Tol.org. 15 November 2016 "Estonia Enjoys Most Internet Freedom, Uzbekistan Among Those With the Least” http://www.tol.org/client/article/26484-freedom-house-report-estonia-uzbekistaninternet-freedom-digital-activism.html

van Laer, J. 2007. "Internet Use and Protest Participation: How do ICTs Affect Mobilisation?” PCW paper. Available at: http://webhost.ua.ac.be/psw/pswpapers/PSWpaper\%20200701\%20jeroen\%20van\%20laer.pdf

Volkov, D. \& Goncharov, S. 2014. "Russian Media Landscape: Television, Print and the Internet" Report, Levada-Centre, June 2014. Available at: http://www.levada.ru/sites/default/files/levada_report_media_0.pdf

Weekes, L.A. 2016. "Country as a Service Estonian e-Residency and the Platformization of the Political". Paper presented at the The Political Economy of Platformization International Colloquium at the University of Leicester, December 6.

Wilson A 2005. Virtual Politics: Faking Democracy in the Post-Soviet World. New Haven: CT.

Yuhas, A. 17 March 2014. Russian propaganda over Crimea and the Ukraine: how does it work? The Guardian. Available at: http://www.theguardian.com/world/2014/mar/17/crimea-crisis-russia-propaganda$\underline{\text { media }}$

Van de Donk, W., Loader, B., Nixon, P., Rucht, D. 2004. Eds. Cyberprotest: New Media, Citizens and Social Movements, London and New York: Routledge. 
Zuckerman, E. 2013. "Cute Cats to the Rescue? Participatory Media and Political Expression in Youth, New Media and Political Participation edited by Allen, D. and Light, J. Cambridge: MIT Press. 